\title{
MORPHOLOGY AND DISCOURSE ANALYSIS
}

\author{
By: \\ Hamka, M.Hum ${ }^{1}$ \\ hamkaharahap@gmail.com
}

\begin{abstract}
$\underline{\text { Abstrak }}$
Selalu ada perspektif ilmiah tentang kejadian nyata di dunia. Sudah ada isu panas di Indonesia tentang keragaman dan persatuan sekarang. Dengan menggabungkan dengan diverse + -ity berarti itu mengacu pada berbagai jenis hal atau orang. Dengan menggabungkan unit + -ity berarti itu mengacu pada sekelompok orang. Hal ini untuk menunjukkan bahwa pendekatan linguistik fungsional sistemik mengambil bagian dalam kasus konteks situasi. Jika itu tentang konteks budaya dan ideologi. Hal ini diteliti secara dinamis, terbukti dan diungkap oleh penelitian lebih lanjut mengenai pengguna bahasa. Penelitian selanjutnya disarankan untuk menyelidiki budaya dan ideologi keragaman dan kesatuan di Indonesia yang terkait dengan hasil analisis morfologi dan wacana.
\end{abstract}

Key words: Morphology, Discourse and Analysis

\section{A. Introduction}

There is always scientific perspective on the real event in the world which is various depending on the focus. Reality shows that many words are going to be debatable which generally goes to only held and justified or interpreted by the holder of power. For example, in Indonesia, the words terrorist, extremist, radicalism, diversity and unity are interpreted look like by only the government instantly with relevant to what they want. This paper limits the words to be analysed by morphology and discourse on diversity and unity in Indonesia.

There is already a hot issue in Indonesia about diversity and unity now. It is started in the end of 2016 until now. Many people say that they are one of diversity to love and to maintain the unity of Indonesia, and still many more people inspire their life without saying that they are the real diversity to love and to maintain the unity. It seems that people are in competing the diversity and unity by different perspectives. One is to say and another one is to inspire.

${ }^{1}$ Hamka is a lecturer of English Education Department for Tarbiyah and Teacher Training Faculty of IAIN Padangsidimpuan. 
By two different perspectives in diversity and unity in Indonesia, they look like in a real competition nationally such in demonstration having two sides for very long time from the end of 2016 until now. It is so real that the competition shows problem in text and context of diversity and unity in Indonesia. This problem has forced people energy especially the government of Indonesia to stop or may be to neutralize the two competitors. This is very important for all people to live in harmony such in diversity and unity. But, the government of Indonesia seems to be in dilemma to neutralize them.

This analysis tries giving such description from scientific perspective on the two words. It describes the text and the context of diversity and unity in Indonesia by systemic functional linguistics analysis. It reveals such firstly by the expression (to say or inspire), the form (formality or informality), the meaning in text (issue or reality), and, secondly is by the situation (what, who and how), the culture (belief, norm and value) and the ideology (personal, scientific or religion) for diversity and unity in Indonesia.

Therefore, doing this analysis hopefully will be an effort contributively to solve such the problem and to neutralize people done by government as one solution ore win-win solution. This will be very useful. Why? For many cases and problems in Indonesia nationally have no solution taken by research. There are only political perspectives, political solutions, political needs, personalities and partial sides to be recommended and forced to do. It means that it is always not neutral anyhow. Thus, science in term of education will minimally neutralize the world harmony especially for diversity and unity in Indonesia by doing a research.

\section{B. Morphology}

Morphology is theory or science of word, its modification and the meaning. O'grady deals that the system of categories and rules involved in word formation and interpretation makes up a language is morphology. ${ }^{2}$ It means that morphology provides system and analysis on word categories and the rules to form the word and to interpreted the meaning. Word is the most familiar analysis in linguistics as the starting point of smallest representative meaning in language.

${ }^{2}$ O'grady, W. \& Dobrovolsky, M. (2000). Contemporary Linguistic Analysis - Fifth Edition. Totonto: Copp Clark LTD. (2000, p. 111). 
Morphology details the word formation and the structures called morphemic analysis. Morphemic analysis requires elements such as the word elements level, morphemic level or word modification level, word function level or word class (type) and meaning (interpretation in general) level in such as tree diagrams. The tree diagrams which are often called tree structures, represent the details of a word's internal organization. ${ }^{3}$ The internal organization or the word means that the word is levelled from general to specific deductively in tree structures as the following examples.

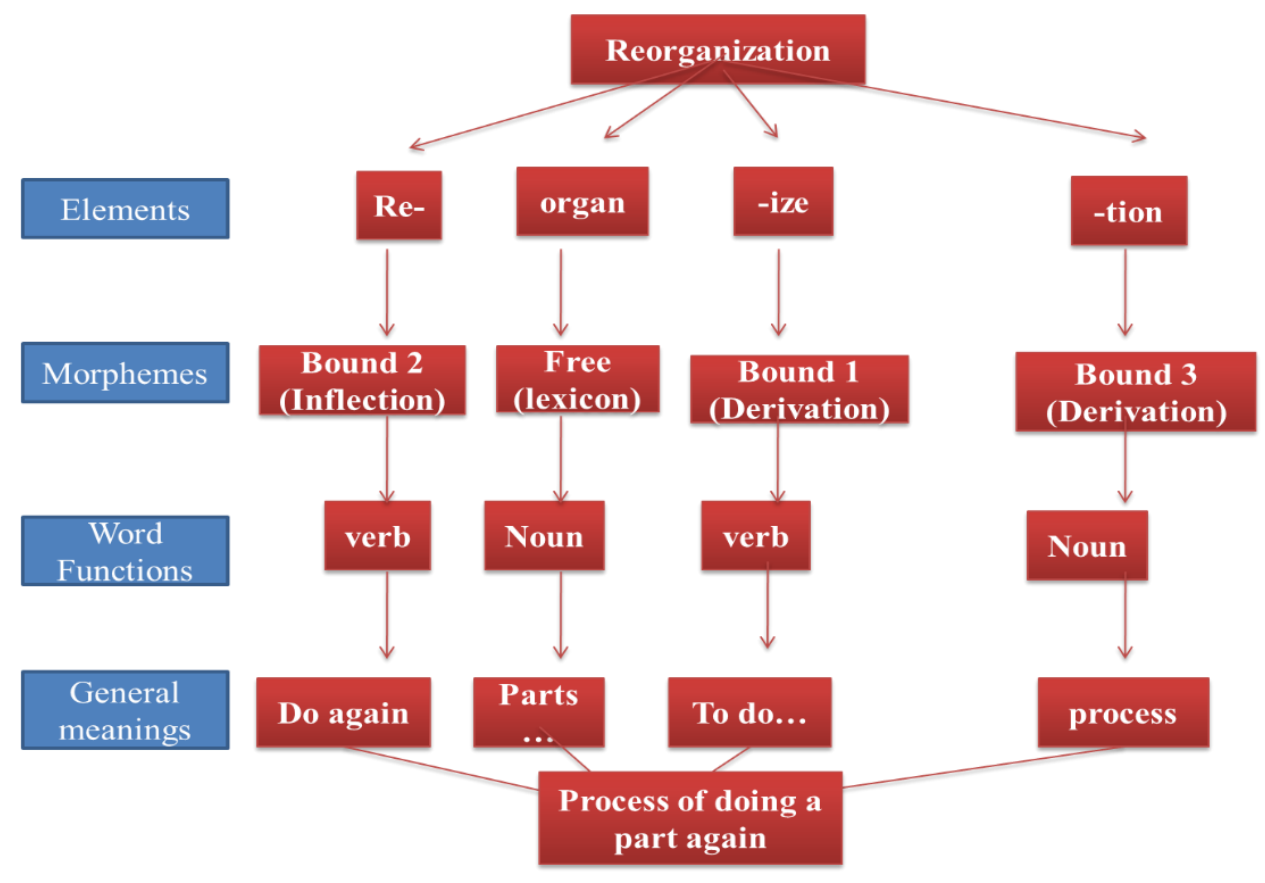

Figure 1: Tree Structures in Morphemic Analysis

\section{Discourse Analysis}

Discourse analysis has two words. Discourse means, text and the meaning in text and the context. Analysis means process of analysing something. Thus, discourse analysis is process of analysing meaning of text and the context. Simsek holds that discourse analysis has been undertaken for a variety of purposes such literary, educational or ethnographic research, and in each case, the object of study

\footnotetext{
${ }^{3}$ O'grady \& Dobrovolsky 2000, Op.Cit. p. 115.
} 
is always 'the text'. ${ }^{4}$ McCarthy specifies that discourse analysis is concerned with the study of the relationship between language and the contexts in which it is used. ${ }^{5}$ It means that language derives it context. Simply, a language plays by text and context of the language user and usage.

Language is human's mind, experience, semiotics (text and context) and organized in grammar or the theory as a system of meaning, form and expression to be as human production. ${ }^{6}$ The system of meaning has two studies. Semantics is the study of meaning in text and pragmatics is the study of meaning in social context. Therefore, discourse analysis comes to join the two meanings in one by applying systemic functional linguistics analysis. By collaborating the two experts (Simsek and McCarthy) on discourse analysis, it can be defined that discourse analysis is to analyse the text in language and what goes with text or context such situation, culture and ideology of the text. The figure 1 may inspire the importance of discourse analysis beyond semantics for demanding experience and pragmatics for giving experience. It means that semantics is theory of meaning in text functions to demand the real experience denotatively and pragmatics is theory of meaning in context functions to give the real experience connotatively. Let see the following figure!

\footnotetext{
${ }^{4}$ Simsek, M. R., A Systemic Functional Analysis of the Two Short Stories: Dicle Universitesi Sosyal Bilimler Enstitusu Dergisi, (DUSBED. YIL-4 S.7), p.74-96, 2012, p. 75.

${ }^{5}$ McCarthy, Discourse Analysis for Language Teachers, (Cambridge: Cambridge University Press, 2000), p. 5.

${ }^{6}$ Hamka. Text and Context in Language as Identity of Human Being, Nation and Country. "Globalization, national culture, and local Wisdom: The Sustainability and Preservation of Culture and Local Wisdom in Facing ASEAN Economic Community". Proceedings of International conference on Culture and Local Wisdom (ICCW), (p.199-208) (2016, p.201)
} 


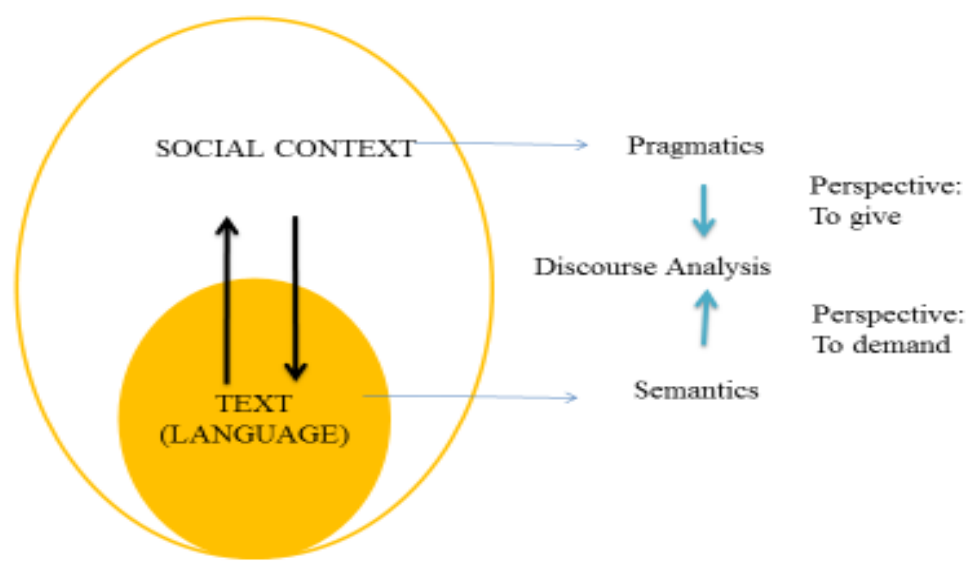

Figure 2 The Scope of Discourse Analysis

\section{Systemic Functional Linguistics}

Systemic functional linguistics is an approach of language study developed by M. A. K. Halliday (a well-known world Linguist from British and now lives in Australia) which English is as the language study (now it has been applied in languages). Halliday introduces systemic functional linguistics as one of linguistic theories to analyse discourse stressing on using language based on its context. ${ }^{7}$ Systemic functional linguistics Elaborates and details the aspects of language; lexico grammar and the application in a study or discourse analysis. Systemic means that it signs as inseparable networks of meaning and it becomes a set way to interpret a choice. Functional means that it designs to account that language is used to such the context of situation, they are field, tenor and mode. That is named metafunctions of language.

Halliday \& Matthiessen propose metafunctions covering ideational function (what/field), interpersonal function (who/tenor) and textual function

${ }^{7}$ Yusuf, M. The Use of Process in English Translation of Suura Al Qashash. "Current Issues on Language and Culture". Proceedings of National Conference on Language and Culture (NCLC), (p.2533) (2016, p. 25). 
(how/mode) ${ }^{8}$ Saragih states that the power of language is seen in its capacity for human need fulfilment. ${ }^{9}$ Saragih also clarifies that human beings need language because it fulfils their needs in that it functions for human beings (1) to represent (field), (2) to exchange (who) and (3) to organize (how) their experience as members of society. ${ }^{10}$

\section{Text}

In producing experience, a man creates a language in a text such in speaking and writing. A text is built up by meaning (semantics and pragmatics), form (morphology and syntax) and expression (phonetics and phonology). In this research, it is not to produce the text, but it is to analyse a text of diversity and unity in Indonesia. Thus, in the process of analysis, or another name of analysis is to comprehend the language in text. Therefore, a text language is comprehended or analysed started by expression (phonetics and phonology), forms (morphology and syntax) and meaning (semantics and pragmatics). This will be illustrated by the following figure.

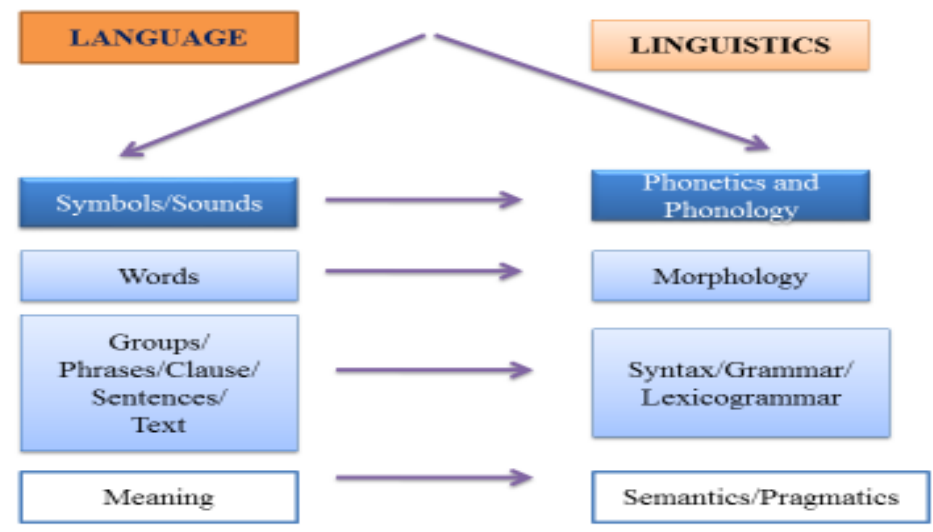

Figure 3 Language Comprehension or Analysis in Text

${ }^{8}$ Halliday, M.A.K. \& Mattiessen, C. An Introduction to Functional Grammar Fourth Edition, London: Edward Arnold (2014, p. 85).

${ }^{9}$ Saragih, A. Empwering Students through Learning English in the Present Context of Indonesia. "Current Issues on Language and Culture". Proceedings of National Conference on Language and Culture (NCLC), (p.1-11) (2016, p. 1).

${ }^{10}$ Saragih, A. Op.Cit. (2016, p. 1). 
A text is linguistic unit that is functional in context. ${ }^{11}$ A text is expressed by only in two ways; they are by symbol or writing analysed by phonetics and sound or speaking analysed by phonology. For example is "diversity" and "unity" are pronounced and symbolized by [dDiva:siti] and [ju:niti]. What is written or spoken must be in term of word analysed by morphology.

The group, phrase, clauses or sentences are analysed by syntax, and all of the linguistic unit or text and also the meaning of test is analysed by semantics, but the meaning in context is analysed by pragmatics. To join the two meanings in text and context, discourse analysis by systemic functional linguistics approach comes for this.

\section{Context}

Naturally, a man behaves an experience together with his situation, culture and ideology. This name is context. Context lies in natural setting. It lies such in the situation of field, tenor and mode of the natural setting. Context of culture requires three fundamental points in it, they are belief, norm and value. Context of ideology has three strata of truth, they are personal truth (personal experience), educational truth and religious truth. Context can be simplified or illustrated simply as the following figure.

Systemic functional linguistics has the theory of language and it is named metafunctions to analyse context of situation. Situation lies on three questions. "What" means to search the field and the logic of the experience and it is named as ideational function. "Who' means to search the tenor of the experience and it is named as interpersonal function. "How" means to search the mode of the experience and it is named as textual function.

\footnotetext{
${ }^{11}$ Saragih, A. Bahasa dalam Konteks Sosial. Medan: Pascasarjana Unimed Press. (2006, p. 4).
} 


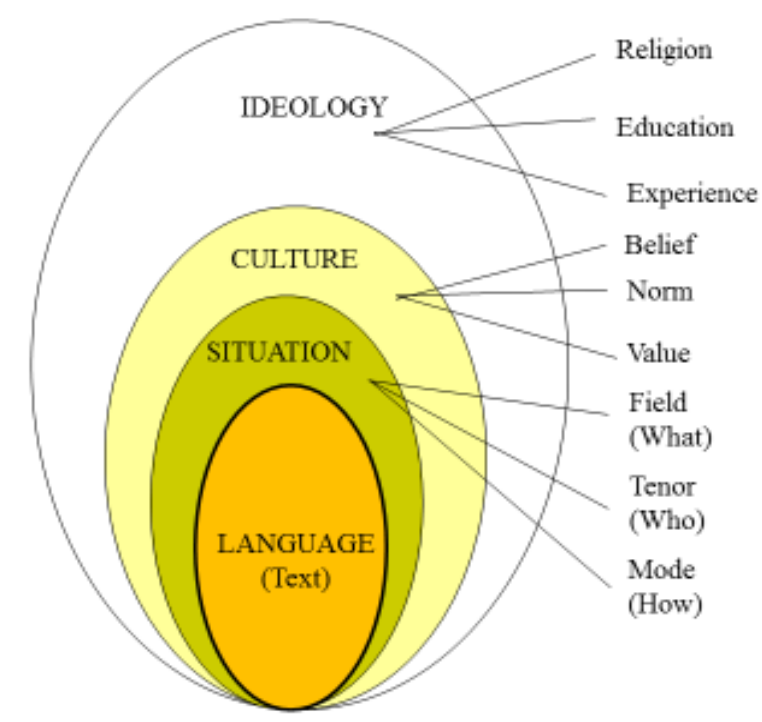

Figure 4 Social Context and the Elements

A simple analysis such the text and the situation can be seen as the following in which clauses are the unit of experiences. The example is situated by firstly, representing experience, that is existent of hot issue, the circumstances are such the manner is already or done, the matter is about diversity and unity, the location of spatial or place is in Indonesia, the location of temporal now. To exchange the experience is by statement declarative or to give information coded by "Subject + Finite" as declarative. To organize the experience is by a simple theme or simple organization. It means that the example organizes the message simply to give information of the existent of hot issue about diversity and unity located in Indonesia in the present time and it is still done or happened.

Table 1

\section{Example of Situational Analysis}

There is already a hot issue in Indonesia about diversity and unity now.

\begin{tabular}{|c|c|c|c|c|c|c|c|}
\hline \multicolumn{3}{|c|}{ There is } & already & a hot issue & $\begin{array}{l}\text { in } \\
\text { Indonesia }\end{array}$ & $\begin{array}{l}\text { about } \\
\text { diversity } \\
\text { and unity }\end{array}$ & now \\
\hline \multicolumn{3}{|c|}{$\begin{array}{l}\text { Proses: } \\
\text { Existential }\end{array}$} & $\begin{array}{l}\text { Circ I: } \\
\text { Manner }\end{array}$ & $\begin{array}{l}\text { Part II: } \\
\text { Existent }\end{array}$ & $\begin{array}{l}\text { Circ II: } \\
\text { Location: } \\
\text { Spatial }\end{array}$ & $\begin{array}{l}\text { Circ III: } \\
\text { Matter }\end{array}$ & $\begin{array}{l}\text { Circ IV: } \\
\text { Location } \\
\text { Temporal }\end{array}$ \\
\hline Sub. & $\mathrm{F}$ & $P$ & Adj. I & Complement. & Adj. II & Adj. III & Adj. IV \\
\hline
\end{tabular}




\begin{tabular}{|l|l|}
\hline Mood & \multicolumn{1}{|c|}{ Residue } \\
\hline $\begin{array}{l}\text { Them } \\
\text { e }\end{array}$ & Rheme \\
\hline
\end{tabular}

The Culture of the above example can be proved by observation to find the real belief, the norm and the value of the language user. The ideology of the example also can be revealed by interviewing the language user about the idea which is based on personal truth, based on research or based on his or he religion. It means, this will be the project in research to show the problems, to elaborate the problems or to improve the problems. It will be better also that the given clauses 1 and 2 in the followings are researched by applying systemic functional linguistic analysis especially in the context of Indonesia today. Examples of the clauses are proposed to be research project:
a. Many people say
"We are one/symbol of diversity and unity in Indonesia"
"We love Indonesia".
'and we maintain the unity of Indonesia".
b. and still many more people inspire life without saying
'we are the real diversity and unity in Indonesia'
'We love Indonesia'
'and we maintain the unity of Indonesia'.

\section{Indonesia}

Language is one focus of attention used as a resource for political movements in Indonesia. Language is very crucial in the future context of the country. Indonesian Independence has been taken into consideration by government for developing national programs since the independence in 1945. Language role in Indonesia can be seen form declaration of Youth Pledge of Indonesia essentially asserts one home country, one nation one uniting language. It means that one uniting language is the focus of the attention of nationalism and political issue.

Today, there is already a hot issue in Indonesia about diversity and unity now. It is started in the end of 2016 until now. Many people say that they are one of diversity to love and to maintain the unity of Indonesia, and still 
many more people inspire their life without saying that they are the real diversity to love and to maintain the unity. It seems that people are in competing the diversity and unity by different perspectives. One is to say and another one is to inspire.

By two different perspectives in diversity and unity in Indonesia, they look like in a real competition nationally such in demonstration having two sides for very long time from the end of 2016 until now. It is so real that the competition shows a problem in text and context of diversity and unity in Indonesia. This problem has forced people energy especially the government of Indonesia to stop or may be to neutralize the two competitors. This is very important for all people to live in harmony such in diversity and unity. But, the government of Indonesia seems to be in dilemma to neutralize them. Thus, this research will analyse the meaning of text and context in diversity and unity in Indonesia by systemic functional linguistics analysis.

\section{Morphology and Discourse Analysis on Diversity and Unity}

\section{Morphological Analysis}

Let see such the illustration of morphological analysis.

\section{Diversity}

\section{Diverse}

Free

$\operatorname{Adj}$

many different types

\section{$-i t y$}

\section{Bound}

\section{N}

\section{Refers to many different types}

Figure 5 Morphological Analysis on Diversity

Diversity is derived from diverse as the free morpheme or lexicon. The word type is adjective. Diverse is perceived as many different types of things or people. Suffix -ity is bound morpheme. The word type is noun. -ity is 
perceived to refer to. By joining diverse + -ity means that it refers to many different types of things or people.

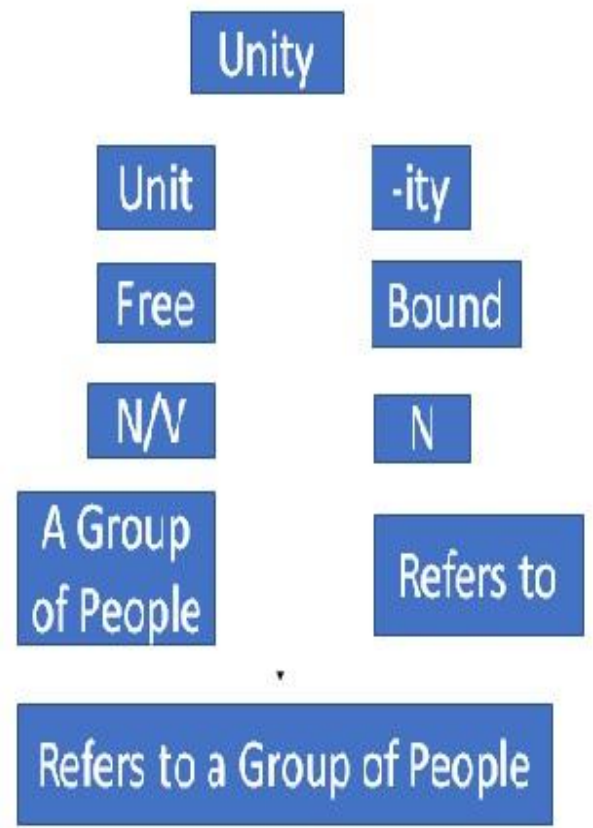

Figure 6 Morphological Analysis on Unity

Unity is derived from unit as the free morpheme or lexicon. The word type is Noun or Verb. Unit is perceived as A group of people. Suffix -ity is bound morpheme. The word type is noun. -ity is perceived to refer to. By joining unit + -ity means that it refers to a group of people.

The two given examples above can clearly explain that scientific perspective. Diversity is to refer to many different types of things or people. Unity is to refer to a group of people. Thus, morphology is very helpful in clarifying such the textual understanding especially a kind of hot issue. Then, let see the two given words above analysed by discourse analysis using systemic functional linguistic approach!

\section{Discourse Analysis}

Let see such the illustration of discourse analysis!

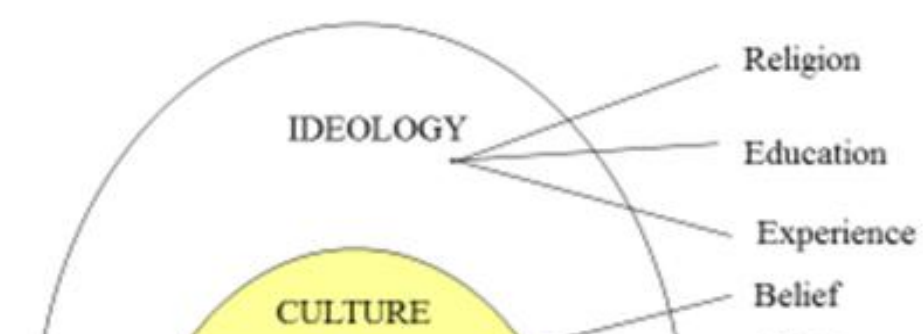




\section{Figure 7 Discourse Analysis on Diversity}

Diversity as the reference to many types of things or people is regularly analysed by firstly context of situation by applying question what as the field of diversity, question who as the tenor of diversity and question how as the mode of diversity. Secondly, Diversity is examined by context of culture by researching the belief of diversity, the norm of diversity and the value of diversity. Finally, diversity is perceived based on ideology use by personal truth, Educational truth scientifically, or religious truth. Here, I just want to show the systemic functional linguistic approach takes a part on the case of context of situation. If it is about the context of culture and ideology. It is dynamically researched, proved and revealed by further research on the language user. 


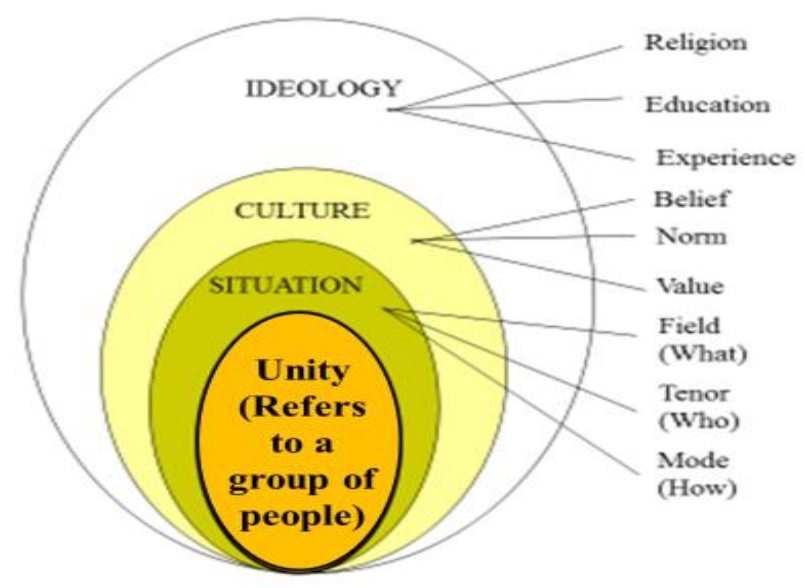

Figure 8 Discourse Analysis on Unity

Unity as the reference to a group of people is regularly analysed by firstly context of situation by applying question what as the field of unity, question who as the tenor of unity and question how as the mode of unity. Secondly, unity is examined by context of culture by researching the belief of unity, the norm of unity and the value of unity. Finally, unity is perceived based on ideology use by personal truth, Educational truth scientifically, or religious truth. I just want to show again here the systemic functional linguistic approach takes a part on the case of context of situation. If it is about the context of culture and religion. It is dynamically researched, proved and revealed by further research on the language user.

\section{E. Conclusion}

1. By joining diverse + -ity means that it refers to many different types of things or people.

2. By joining unit + -ity means that it refers to a group of people.

3. This is to show that the systemic functional linguistic approach takes a part on the case of context of situation. If it is about the context of culture and ideology. It is dynamically researched, proved and revealed by further research on the language user. 
4. The further research is suggested to investigate the culture and the ideology of diversity and unity such in Indonesia connected to the result of morphology and discourse analysis.

\section{REFERENCE}

Halliday, M.A.K. \& Mattiessen, C. (2014). An Introduction to Functional Grammar Fourth Edition, London: Edward Arnold.

Hamka. (2016). Text and Context in Language as Identity of Human Being, Nation and Country. "Globalization, national culture, and local Wisdom: The Sustainability and Preservation of Culture and Local Wisdom in Facing ASEAN Economic Community". Proceedings of International conference on Culture and Local Wisdom (ICCW), (p.199-208).

McCarthy, M. (2000). Discourse Analysis for Language Teachers. Cambridge: Cambridge University Press.

O’grady, W. \& Dobrovolsky, M. (2000). Contemporary Linguistic Analysis - Fifth Edition. Totonto: Copp Clark LTD.

Saragih, A. (2006). Bahasa dalam Konteks Sosial. Medan: Pascasarjana Unimed Press.

Saragih, A. (2016). Empwering Students through Learning English in the Present Context of Indonesia. "Current Issues on Language and Culture”. Proceedings of National Conference on Language and Culture (NCLC), (p.1-11).

Simsek, M.R. (2012). A Systemic Functional Analysis of the Two Short Stories. Dicle Universitesi Sosyal Bilimler Enstitusu Dergisi (DUSBED. YIL-4 S.7), (PP.74-96).

Yusuf, M. (2016). The Use of Process in English Translation of Suura Al Qashash. "Current Issues on Language and Culture". Proceedings of National Conference on Language and Culture (NCLC), (p.25-33). 